\title{
Cardioprotection with sevoflurane during off-pump coronary artery surgery
}

\author{
I Husedzinovic, N Bradic \\ From 23rd World Congress of the World Society of Cardio-Thoracic Surgeons \\ Split, Croatia. 12-15 September 2013
}

\section{Objective}

To evaluate a cardioprotective effect of sevoflurane in patients underwent off-pump coronary artery bypass grafting with normal preoperative left ventricular function.

\section{Methods}

Study included 48 patients induced in anesthesia with 8 vol.\% sevoflurane within high $100 \%$ oxygen flow $(5 \mathrm{~L} / \mathrm{min})$. Patients randomized into two groups: sevoflurane group (n =24) in which anesthesia maintained with 1 MAC of endtidal sevoflurane concentration, and propofol group $(\mathrm{n}=$ 24 ), in which anesthesia maintained with continuous propofol infusion in doses of 2 to $3 \mathrm{mg} / \mathrm{kg} / \mathrm{h}$. Inclusion criteria were angiographically verified CAD and LVEF higher than 40\%. Exclusion criteria were: AV conduction disturbances, AF with rapid ventricular response, myocardial infarction within 6 months, or diabetes mellitus. Pulmonary artery catheter used for the consecutive hemodynamic measurements. Cardiac index, heart rate, mean arterial pressure and central venous pressure were measured 5 minutes after anesthesia induction, on the beginning of ischemia, 15 minutes after ischemia and 15 minutes after sternum closure. For analysis between groups and time-points, a two-way analysis of variance (ANOVA) was performed and only $\mathrm{p}<0.05$ was considered statistically significant.

\section{Results}

There were no differences within group and between groups for the heart rate, mean arterial pressure and central venous pressure during surgery. There were no significant differences in cardiac index values within sevoflurane group. In propofol group significant

\footnotetext{
* Correspondence: nbradic@kbd.hr

Clinic of Anesthesiology, Reanimatology and Intensive Medicine, University Hospital Dubrava, Zagreb, Croatia
}

(c) 2013 Husedzinovic and Bradic; licensee BioMed Central Ltd. This is an Open Access article distributed under the terms of the Creative Commons Attribution License (http://creativecommons.org/licenses/by/2.0), which permits unrestricted use, distribution, and reproduction in any medium, provided the original work is properly cited.
Cite this article as: Husedzinovic and Bradic: Cardioprotection with sevoflurane during off-pump coronary artery surgery. Journal of Cardiothoracic Surgery 2013 8(Suppl 1):O158. mia $(p<0.001)$. There were between-group differences in cardiac index values on the beginning of ischemia and 15 minutes after ischemia $(\mathrm{p}=0.002$, and $\mathrm{p}=0.011$, respectively).

\section{Conclusion}

Cardiac function was preserved in patients anesthetized with sevoflurane comparing with patients treated with propofol.

Published: 11 September 2013

Submit your next manuscript to BioMed Central and take full advantage of:

- Convenient online submission

- Thorough peer review

- No space constraints or color figure charges

- Immediate publication on acceptance

- Inclusion in PubMed, CAS, Scopus and Google Scholar

- Research which is freely available for redistribution

\section{() Biomed Central}

